\title{
Finite verb forms in Beja (Cushitic): Labels vs functions, a historical perspective
}

\author{
Martine Vanhove*
}

\section{INTRODUCTION}

Spoken mainly in Eastern Sudan by over 1,100,000 speakers (1993 census, the last to contain a language question; the number has probably risen since then), and also in Northern Eritrea by some 60,000 speakers ${ }^{1}$, Beja (ISO 639; locally called bedawje: $=t$ ) is the sole member of the North-Cushitic branch of Afroasiatic. Figure 1 below presents the geographical position of Beja vis-à-vis the Cushitic branch.

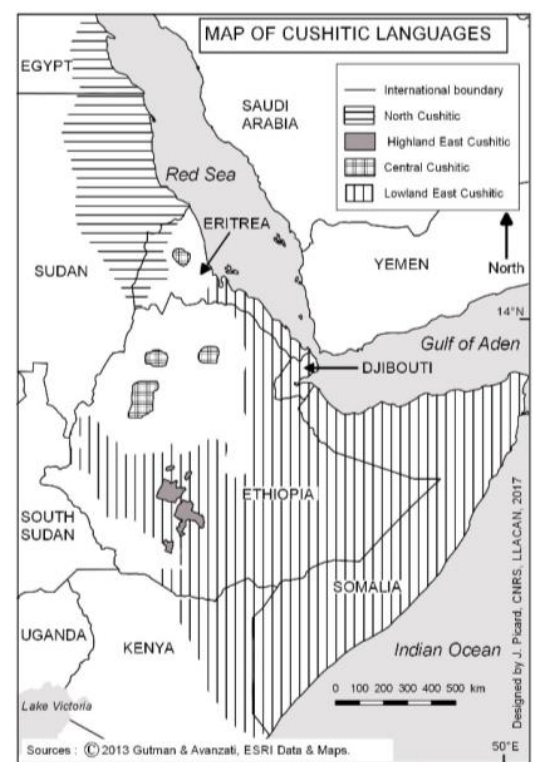

Figure 1: Map of Beja and Cushitic languages.

\footnotetext{
* LLACAN (CNRS - INALCO - Université Sorbonne Paris-Cité). Courriel : martine.vanhove@cnrs.fr.

${ }^{1}$ It is on the verge of extinction (if not extinct) in Southern Egypt.
} 
Descriptions of this language by Western scholars only date back to the second half of the 19th century. The first grammatical sketch was written by Munzinger (1864: 341-369), a Swiss administrator and explorer of the Horn of Africa. It consisted of a short eleven-page phonetic and morphological description, followed by a few examples, a short text, and a fifteen-page lexicon organized by grammatical categories. The first published grammar of Beja was of the Northern variety, and is credited to the Swedish scholar Herman Almkvist; it came out between 1881 and 1885 and also contains texts and a lexicon. In his grammar published in 1893-1894, the Austrian scholar, Leo Reinisch, provided a more accurate and refined analysis of the same variety, with two additional volumes consisting of a collection of texts and a dictionary. Furthermore, Reinisch's grammar contains comparative notes on other Afroasiatic and NiloSaharan languages. Some 35 years elapsed before a third grammar was published, this time describing the central variety and modestly entitled $T u$ Bedawiye. An elementary handbook for the use of Sudan government officials, by a British administrator of the Beja-speaking area in Sudan, E.M. Roper (1928). It also contains a collection of sentences and texts, and a lexicon. In 1964, Richard H. Hudson completed his PhD thesis, which was a Firthian-based approach of the phonology and morphology of the central variety spoken in Port-Sudan. It was followed by two grammatical sketches in 1974 and 1976. During a short stay in Port-Sudan, the Swedish typologist, Östen Dahl, filled in his TAM questionnaire with a Beja speaker and published a brief analysis of the semantic values of finite verb forms in 1984. In 1995 my French colleague, the late Didier Morin, wrote a grammatical sketch of the Southern variety that aimed to provide information for a better understanding of a selection of Beja tales. In 2007, Klaus and Charlotte Wedekind, two SIL missionaries in Eritrea, published a pedagogical grammar of "East Sudan Beja", which mentions dialectal variation and includes a CD with sound files of the examples. In 2017, I completed a typologically oriented functional grammar of the central variety (Vanhove 2017a) based on textual data I recorded in Sudan between 2000 and 2011. This grammar was preceded by an online grammatical sketch (2014a). The nonelicited examples in both grammars are referenced and freely accessible online (Vanhove 2014b and 2017b).

In addition to the above descriptions, other scholars have studied the verbal morphology of Beja from a comparative point of view with other Cushitic and Afroasiatic languages, most significantly Cohen (1972, 1973, 1988), Zaborski (1975), Voigt (1988), and Appleyard (2004, 2007). All of them used part of the above-mentioned works. Appleyard (2007) also proposed an analysis of the morphology based on previous descriptions and data.

Throughout these publications, the authors used a number of overlapping labels for the verb paradigms.

Before turning to the core of this article, it is necessary to provide a brief overview of basic verb paradigms. Beja has two morphologically-based verb classes: V1, conjugated with prefixes (or infixes in the singular of disyllabic stems, and suffixed plural markers), and V2, conjugated with suffixes. Each class 
has three basic finite paradigms in the indicative ${ }^{2}$ which for the purposes of this article I will label by one of their formal properties: in-form, $i$-form, and $i$-form. The paradigms of the underived verb forms are provided in Tables 1 and $2 .^{3}$

\begin{tabular}{|c|c|c|c|c|c|c|}
\hline & \multicolumn{2}{|c|}{ in-form } & \multicolumn{2}{|c|}{$i$-form } & \multicolumn{2}{|c|}{$i$-form } \\
\hline V1 & SG & PL & SG & PL & SG & PL \\
\hline $\begin{array}{l}1 \\
2 \mathrm{M} \\
2 \mathrm{~F} \\
3 \mathrm{M} \\
3 \mathrm{~F}\end{array}$ & 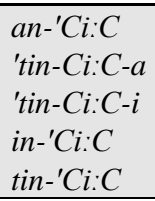 & $\begin{array}{l}\text { ne:-'CiC } \\
\text { 'te:-CiC-na } \\
\text { 'e:-CiC-na }\end{array}$ & $\begin{array}{l}a-{ }^{\prime} C i C \\
\text { 'ti-CiC-a } \\
\text { 'ti-CiC-i } \\
i-{ }^{-} C i C \\
t i-{ }^{\prime} C i C \\
\end{array}$ & $\begin{array}{l}n i-{ }^{\prime} C i C \\
\text { 'ti-CiC-na } \\
\text { 'i-CiC-na }\end{array}$ & 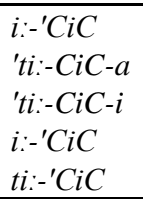 & $\begin{array}{l}n i:-{ }^{\prime} C i C \\
' t i:-C i C-n a \\
' i:-C i C-n a\end{array}$ \\
\hline $\mathrm{V} 2$ & & & & & & \\
\hline $\begin{array}{l}1 \\
2 \mathrm{M} \\
2 \mathrm{~F} \\
3 \mathrm{M} \\
3 \mathrm{~F}\end{array}$ & $\begin{array}{l}\text {-'ani } \\
\text {-'tnija } \\
\text {-'tini: } \\
\text {-'i:ni } \\
\text {-'tini }\end{array}$ & $\begin{array}{l}-n e j /-n a j \\
-t e: n(a) \\
-e: n(a)\end{array}$ & $\begin{array}{l}-' a n \\
-\operatorname{ta}(n) \\
-\operatorname{taj} /-\operatorname{ta}(n) \\
-j a(n) \\
-\operatorname{ta}(n)\end{array}$ & $\begin{array}{l}-n a \\
-\operatorname{ta} n(a) \\
-\operatorname{ja:n}(a)\end{array}$ & $\begin{array}{l}-i \\
-t i j a \\
-t i \\
-i \\
-t i\end{array}$ & $\begin{array}{l}-n i \\
-t i: n(a) \\
-i: n(a)\end{array}$ \\
\hline
\end{tabular}

Table 1: Paradigms of monosyllabic V1 and all V2 verbs

\begin{tabular}{|c|c|c|c|c|c|c|}
\hline & \multicolumn{2}{|c|}{ in-form } & \multicolumn{2}{|c|}{$i$-form } & \multicolumn{2}{|c|}{$i:$-form } \\
\hline V1 & $\mathrm{SG}$ & PL & $\mathrm{SG}$ & PL & SG & PL \\
\hline 1 & $a$-'CanCi:C $^{-}$ & $n i-C a^{\prime} \mathrm{CiC}$ & $a-^{\prime} C C i C$ & $n e:-\mathrm{Ca}^{\prime} \mathrm{CiC}$ & $i \mathbf{-}^{\prime} C \mathrm{CiC}$ & $n i \mathbf{-}^{\prime} \mathrm{CCiC}$ \\
\hline $2 \mathrm{M}$ & 'CanCi:C-a & $\begin{array}{l}t i-{ }^{\prime} \mathrm{CaCiC}- \\
n a\end{array}$ & 'ti-CCiC-a & $\begin{array}{l}\text { te:-'CaCiC- } \\
\text { na }\end{array}$ & 'ti:-CCiC-a & 'ti:-CCiC-na \\
\hline $2 \mathrm{~F}$ & 'CanCi:C-i & & 'ti-CCiC-i & & 'ti:-CCiC-i & \\
\hline $3 \mathrm{M}$ & $\mathrm{Can}^{\prime} \mathrm{Ci}: \mathrm{C}$ & $\begin{array}{l}i-^{\prime} \mathrm{CaCiC}- \\
n a\end{array}$ & $i-^{\prime} C C i C$ & $\begin{array}{l}e:-{ }^{\prime} \mathrm{CaCiC}- \\
n a\end{array}$ & $i$ - $^{\prime} C \mathrm{CiC}$ & 'i:-CCiC-na \\
\hline $3 \mathrm{~F}$ & $\mathrm{Can}^{\prime} \mathrm{Ci}: \mathrm{C}$ & & $t i-^{\prime} C C C$ & & $t i:-{ }^{\prime} C C i C$ & \\
\hline
\end{tabular}

Table 2: Paradigms of disyllabic V1 verbs

A small set of verbs displays different morphology. A few stative and middle verbs have no $i$-form at all (and use the $i$-form instead), and these verbs, as well as those with a $(\mathrm{Ci} / \mathrm{Ha}) \mathrm{Co} \mathrm{C}$ or $(\mathrm{Ci}) \mathrm{Ce}: \mathrm{C}$ pattern, have no in-form but a corresponding paradigm with an $-i$ suffix in addition to the prefixed personal

\footnotetext{
${ }^{2}$ There is a fourth one which grammaticalized from the manner converb and the copula. It expresses a resultative perfect. It won't be dealt with in this paper.

3 Abbreviations : ABL ablative; ACC accusative; AOR aorist; COORD coordination; CSL causal; CVB converb; DEF definite; DIR directional; DISTR distributive; EP epenthetic; GEN genitive; GNRL general; IMP imperative; INDF idefinite; INT intensive; IPFV imperfective; LOC locative; M masculine; MID middle; MNR manner; NOM nominative; OBJ object; PFV PERFECTIVE; PL plural; POSS possessive; PRO pronoun; PROX proximal; RCPT recipient; REFL reflexive; REL relator; SEQ sequential; SG singular; SMLT simultaneity.
} 
indices. A few others are highly irregular (for details, see Vanhove 2017a: 6670).

Section 2, Confusing Terminology, presents the various terminologies adopted by the above-mentioned authors. In Section 3, Synchronic Approaches, the synchronic labels used in grammatical descriptions based on first-hand data are discussed and in Section 4, Comparative Approaches, I comment briefly upon the labels used by linguists adopting a historical comparative approach. Section 5 wraps up the findings.

\section{CONFUSING TERMINOLOGY}

Table 3 below provides an overview, from the most recent to the oldest publication (and by author when necessary), of the terminology used for the three basic indicative finite verb forms of Beja in the works of the thirteen authors mentioned above. Note that Almkvist overlooked the third paradigm which he conflated with the other two, ${ }^{4}$ and used the label "Aorist" for a periphrastic construction expressing a future-oriented potential value (which is not included in this paper).

\begin{tabular}{|l|l|l|l|}
\hline & in-form & i-form & i-form \\
\hline $\begin{array}{l}\text { Vanhove (2014a, } \\
\text { 2017a) }\end{array}$ & Imperfective & Perfective & Aorist \\
\hline Vanhove (2005) & imperfective & perfective & narrative \\
\hline Wedekind (2007) & Imperfect & Perfect & $\begin{array}{l}\text { Past Continuous / } \\
\text { Pluperfect }\end{array}$ \\
\hline Appleyard (2007) & present & past & aorist \\
\hline Appleyard (2004) & present & past & old past \\
\hline Morin (1995) & inaccompli & accompli & conditionnel \\
\hline Voigt (1988) & Imperfekt & $\begin{array}{l}\text { Aorist / } \\
\text { Präteritum }\end{array}$ & Perfekt \\
\hline Dahl (1984) & present & perfective past & imperfective past \\
\hline Hudson (1976) & present & preterit & past \\
\hline Zaborski (1975) & Present & Old Present & Old Past \\
\hline $\begin{array}{l}\text { Cohen (1972, 1973; } \\
\text { 1988) }\end{array}$ & $\begin{array}{l}\text { présent; } \\
\text { inaccompli }\end{array}$ & $\begin{array}{l}\text { Passé / parfait; } \\
\text { accompli }\end{array}$ & $\begin{array}{l}\text { plus-que-parfait / } \\
\text { parfait / } \\
\text { conditionnel }\end{array}$ \\
\hline Roper (1928) & present & past & conditional \\
\hline Reinisch (1893-94) & präsens & perfect & plusquamperfect \\
\hline Almkvist (1881) & Präsens & Perfekt & $\emptyset$ \\
\hline Munzinger (1864) & Aorist & Perfect & Plusquamperfect \\
\hline
\end{tabular}

Table 3: Comparison of finite verb form terminology for Beja

${ }^{4}$ The conflation is not always transparent and Appleyard (2007: 468) understood the lack of the third finite form in Almkvist tables of paradigms as a dialectal feature. 
At first glance, two major comments are in order. First, a quick look at Table 3 immediately reveals a division between the aspectual and/or temporal stances of the authors, with the possible addition of a modal distinction (Roper, Cohen, Morin), as well as terminology which directly reflects the diachronic approach of the author (Zaborski). Secondly, columns 3 and 4 show diverse and confusing terminology, to the point that in some instances, the same labels cover two different finite paradigms (even three if one includes Munzinger's terms from column 2), depending on the author.

Such confusing terminology partly reflects critical issues in the analysis of the functions and semantic values of the paradigms. As Hudson stated in his last grammatical sketch,

[o]ne of the main outstanding problems in the study of Beja is to identify more precisely the meanings of ... inflectional categories of the verb. Thus the translations given should be taken as rough guides to meaning (as should the names given to the categories). Hudson (1976: 115)

Until Vanhove (2017a), no analysis of the functions and semantic values of the verb paradigms based on natural data had been carried out and most authors did not provide any functional and semantic justifications for the labels used. Consequently this article cannot discuss previous analyses since they are lacking, the only exception being the short article of Dahl (discussed in the following sections) who based his study on scanty elicited data.

The terminological issue is also partly linked to the linguistic tradition and theoretical approaches adopted more or less consciously by linguists, as we will see more in detail in Sections 3 and 4. For instance, the different terminology used by Cohen $(1972,1973,1988)$ and Vanhove $(2014 a, 2017 a)$ are either due to recycling of previous authors' terminology or to the linguists' theoretical position with respect to aspect. Cohen simply translated Reinisch's and Roper's labels "présent", "passé", "parfait", "plus-que-parfait", "conditionnel" in his 1972 and 1973 papers, but in his 1988 chapter, he consistently propounded his own aspect-oriented stance about the basic systems of Cushitic and Afroasiatic, using "accompli" and "inaccompli". As for myself, the choice of "Narrative" at an initial stage of my analysis was a result of my dissatisfaction with the previous labels and the fact that at that time, I had mainly found the use of this verb form in tales. I decided to change it to "Aorist", which I borrowed from Appleyard, for functional and "traditional" reasons that I will explain in Section 3.2.5, "Aorist".

The following statement by Dahl (where he justifies using a questionnaire for his cross-linguistic survey) also applies to most grammars and grammatical sketches of Beja:

[m]ost extant descriptions of the world's languages contain almost no information at all about the use of TMA [tense, mood, aspect] categories except for the labels that the grammarian has chosen to apply to them. Even if these labels are not just taken over from school grammar - as is often the case - the terminology tends to be too 
idiosyncratic to warrant proper comparisons with other languages, and the few examples given are more often than not of little help, too. (Dahl 1985: 2)

\section{SYNCHRONIC APPROACHES}

\section{The in-form}

The labels of this paradigm are the least problematic of the three finite verb forms. Apart from the first short description by Munzinger (1864) who labeled it "Aorist" (perhaps under the influence of the traditional term for Greek, but in non-prototypical usage), they show no interference with the labels for the other two forms.

There is an obvious split between linguists who favor aspectual terminology and those who prefer temporal, and this is (partly) related to the history of linguistics. In the first category we find the most recent descriptions, those of Morin, the Wedekinds and Vanhove, all dating from a time when (competitive) aspectual theories were better established and aspectual systems better understood.

Morin states, in his introductory paragraph, that "[1]e système verbal repose sur une opposition aspectuelle et modale" (Morin 1995: 50), ${ }^{5}$ and further adds translational equivalents: "[1]'inaccompli correspond à un présent général ou à un futur proche" (Morin 1995: 51), ${ }^{6}$ which give the impression that the semantic values of the paradigm are exclusively temporal.

As for the Wedekinds, they provide a typical definition of the two aspectual labels they use: "Beja verbs use the "Perfect Aspect" if at a particular time the event is complete, and they use the "Imperfect", if it is still incomplete" (Wedekind \& Wedekind 2007: 149), but immediately afterwards they shift their aspectual stance to a more temporal approach, using a translational and a vague quantitative argument:

these two aspects are not entirely neutral as far as "times" or "tenses" are concern[e]d, such as "Past" or "Present".

- The "Present Tense" is usually expressed by the "imperfect aspect".

- The "Past Tense" is usually expressed by the "perfect aspect". (Wedekind \& Wedekind 2007: 149)

Again, on the following page, they seem to hesitate between an aspectual and a temporal approach of these two finite forms and use both types of terminology: "In addition to the two tense[s] / aspects "present / imperfect" and "past / perfect" there are some specific "tense / aspect" forms." (Wedekind \& Wedekind 2007: 150). It is impossible to know, from such scanty information and the decontextualized examples they provide, if this fluctuation is due to their mental image of the linguistic background of the Western "learners" their grammar is intended for - e.g., in school grammars, "tense", "present" (or "past") are more

5 'The verbal system is based on an aspectual and modal distinction'.

6 'The imperfective corresponds to a general present or a near future'. 
widespread - or to some analytical debate where the in-form is interpreted as combining tense and aspect. Besides, the use of "imperfect" (and "perfect") instead of "imperfective" (and "perfective") is probably due to the influence of traditional German terminology ("Perfekt" and "Imperfekt"), although in English the terms do not cover the same semantic values as the ones they postulate for Beja (in German schools, "Imperfekt" is used alternatively to "Präteritum" (!), e.g. ich ging 'I went', Y. Treis p.c.).

In Vanhove (2017a: 127), I provide a definition of the "imperfective" which directly derives from Cohen's (1988) approach to aspect, i.e. a finite verb form whose primary semantic value is to represent an unbounded process or state, considered from an ongoing point of view. This definition is akin to those of many other theories of aspects, especially the typologically and diachronically oriented ones (e.g. Comrie 1976; Bybee et al. 1994). The Beja examples show that this verb form can be used in all temporal contexts (present, past, future), and in independent as well as dependent clauses. The imperfective is not used in the reportive sense (including general truth), but it is used to express the concomitance of an ongoing process with the moment of enunciation or between two events, as illustrated in (1), i.e. what is often termed "progressive" or "durative" in languages which have grammaticalized a dedicated verb form such as be $V$-ing in English. (2) is an example of the imperfective used in a past context; (3) and (4) are examples in a context of future in independent (a promise) and dependent clauses, respectively.

$$
\begin{aligned}
& \begin{array}{lll}
\text { gana:j } & \text { wali: } k-i: n i=b & e:- \text { msiw } \\
\text { gazelle } & \text { cry-IPFV.3SG.M=REL.M } & \text { 1SG-hearlINT.IPFV }
\end{array} \\
& \text { 'I am hearing a gazelle who is crying.' (05_Eritrea_250-252) }{ }^{7}
\end{aligned}
$$

$$
\begin{aligned}
& \text { hi:da:b ri:ba:b-ja:n } \quad \text { ii:ba:b-e: } \quad \text { ha:f=i:b } \\
& \text { together travel-PFV.3PL travel-CVB.SMLT country=LOC.SG } \\
& \begin{array}{lll}
\text { - ganif-na }=e: b & 0:=d o: r & \text { jha:m dha:j }
\end{array} \\
& 3 \mathrm{M} \text {-kneellMID.PFV-PL=REL.M DEF.SG.M.ACC=time leopard DIR } \\
& j ?-i=t \quad e:=k a m \\
& \text { come-AOR.3SG.M=COORD DEF.PL.M.ACC }=\text { camel } \backslash P L \\
& j i=i:- \text { biri- } n=e:=n a:=j e: b \quad \mathrm{ka}: \mathrm{m} \text { ho:j } \\
& \text { REL.PL.M=3-have } A \text { AOR-PL=REL=thing=LOC.PL camel ABL. } 3 \\
& \text { danri } \\
& \text { killlIPFV.[3sG.M] }
\end{aligned}
$$

\footnotetext{
7 The information between parentheses refers to the number of the examples in the two online annotated corpora CorpAfroAs and Cortypo. Abbreviations in glosses are listed at the end of the article. My gratitude goes to all my Beja consultants, in particular Ahmed Abdallah Mohamed-Tahir and his family in Sinkat, my colleague Mohamed-Tahir Hamid Ahmed, and my hosts in Khartoum, Yacine Ahmed Hamid and his family. I also wish to thank the editors of this special issue, the Labex EFL, and the three anonymous reviewers for fruitful comments.
} 
(3)

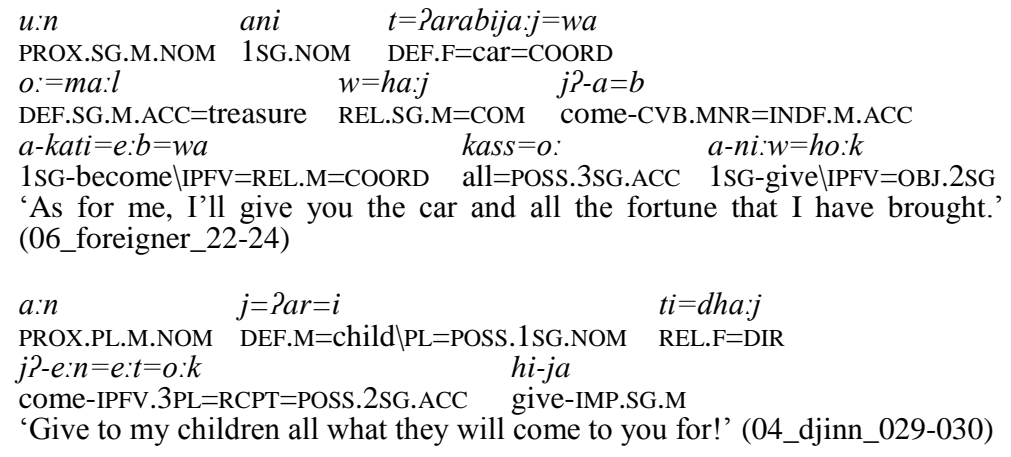

The second group of authors is represented by linguists who, with the exception of $\mathrm{Dahl}^{8}$, worked at a time when aspect as a grammatical category was ill-recognized or had hardly expanded beyond Slavic languages. They all termed the in- form as "Present". Dahl (1984: 93) is the only one who provided what can be regarded as a justification for his label, stating that the "present" is "[u]sed for all kinds of present time reference and also for predictions about the future. (It is unclear if it can be used in the reportive sense.)" In Dahl (1985: 154), the "present" is regarded as the default category (in terms of frequency in his questionnaire). Nevertheless on p. 186, Beja appears in the table entitled "Major TMA categories with morphological expression" as a language having a "perfective", "imperfective" and "PASTid" (i.e. a past applied to dynamic contexts and imperfective contexts), for reasons the author does not discuss for Beja here or elsewhere in the book or in his 1984 article. However the label "present" seems to actually be in line with the methodology used in Dahl's crosslinguistic survey, which is based on the identification of the basic vs. secondary meaning of a category (Dahl 1985: 9). But for this form, as well as the other two, there is a possibility that Dahl's choice of a label and analysis can be explained by the fact that he had to limit his survey to the major TAM categories used in affirmative, declarative, non-embedded, active constructions, to ensure that the cross-linguistic database be manageable (Dahl 1985: 53), and by the fact that he postulates a strong correlation between "present" and "imperfective".

\section{The $i$-form and the $i$-form}

These two forms are treated in the same section because of the large terminological overlap. Part of the overlap, even in synchronic descriptions, may be due to a conscious or unconscious awareness of the historical evolution of the two finite forms and to national traditions. The various labels refer either to aspectual or temporal approaches for both forms, and also to mood for the $i$ :form. Again, for these forms the history of the development of linguistic theories

${ }^{8}$ Dahl (1985: viii) follows Comrie's definitions of the various aspectual catgories. 
of aspect played a role in the authors' choices of labels, but also crucially their native (or working) language traditions, or their linguistic training.

\section{"Perfect"}

The aspectual label "Perfekt" (or "perfect"), the oldest one, is obviously due to the influence of the German tradition which uses it for periphrastic constructions of the type ich bin gegangen 'I have come', ich habe gegessen 'I have eaten'. All the linguists who used it either come from the German-speaking world or wrote their grammar in German. It is applied to the $i$-form by Munzinger (Swiss), Almkvist (Swedish, writing in German), Reinisch (Austrian) and Wedekind-s (German). Only Wedekind \& Wedekind (2007: 149) provide a definition (which actually corresponds to that for "perfective"): "Beja verbs use the "Perfect Aspect" if at a particular time the event is complete". But like for his "Imperfect" (see Section 3.1, "The in-form"), the authors limit it almost exclusively to past contexts: "The 'Past Tense' is usually expressed by the 'perfect aspect'." But unlike the periphrastic German paradigm, the decontextualized examples are systematically translated by a "preterit" form in English, similarly to the use of the non-periphrastic past tense of German by authors writing in German. We will see in Section 4, that the German comparatist Voigt reused this label, but for the $i$ :-form.

\section{"Pluperfect" and "past continuous"}

These two temporal labels also belong to the German-speaking linguists, who use it consistently for the $i$--form, and never for the $i$-form. Wedekind \& Wedekind (2007: 155), who use both labels, specify that the "CContinuous Past' is expressed by verbs with ' $i i$ ' and refers to habitual, repeated actions of the (more distant) past"', which are indeed some of the semantic values of this finite form (see below Section 3.2.5, "Aorist").

\section{"Past”, "preterit”, "imperfective past”, "perfective past”}

The first two temporal labels come from the British linguists. Roper used "past" for the $i$-form (and "conditional" for the $i$-form, see below Section 3.2.6), while Hudson introduced the label "preterit" (taken up by the comparatist Voigt), the latter having a transparent heritage from traditional grammars of English, but kept the term "past" for the $i$--form which he glosses as "I used to + infinitive", "I had + past participle", or "I might + infinitive", and which like the previous labels of Section 3.2.2, "Pluperfect and past continuous", also correspond to some functions of this verb form (habitual, anterior past, modal).

The typologist Dahl (Swedish, writing in English), specialist of tense, aspect and mood, is the only one to have introduced an aspectual dimension together with the "past" label. He characterizes the $i$-form as a "perfective past", and the $i$ :-form as an "imperfective past": "The imperfective past is used for on-going actions or habits in the past. The perfective past is used for most other cases of 
past time reference." (Dahl 1984: 93-94). These functions of the $i$--form are indeed part of its meaning in independent clauses (see below, Section 3.2.5).

\section{"Perfective"}

This label (on its own) is only used by the French linguists, who happen to also be specialists of Semitic languages for which aspectual analyses predominate. It is only applied to the $i$-form. Morin (1995: 51), explains that "[1]' accompli a une valeur de terminatif'. 9 In Vanhove (2017a), again following Cohen's (1989) approach of aspect, I characterized the "perfective" as follows:

Le paradigme de l'accompli a pour fonction de marquer un procès ou un état borné, délimité. Il exprime la relation prédicative "en tant qu'elle est advenue, qu'elle constitue un événement" (Cohen 1989: 67), indépendamment de tout repère temporel.

De ce fait, cette conjugaison est neutre du point de vue temporel et se trouve aussi bien en contexte de passé, de présent que de futur, même si ce dernier est plus rare. ${ }^{10}$ (Vanhove (2017a: 124-125)

In natural examples these forms are found with completed events, typically at the beginning (5) and the end (6) of narratives, to mark anteriority in the past (7), in performative contexts (8), and in predictions considered unavoidable, typically in the apodosis of conditional clauses (9).

$$
\begin{array}{lll}
a-d i f=h o: b & \text { biri } \quad d h=e: & \text { i-ja:m } \\
\text { 1SG-leavelPFV=when } & \text { rain DIR=POSS.1sG.ACC } & \text { 3SG.M-rainlINT.PFV } \\
\text { 'When I left, it rained over me.'(01_shelter_012-013) }
\end{array}
$$

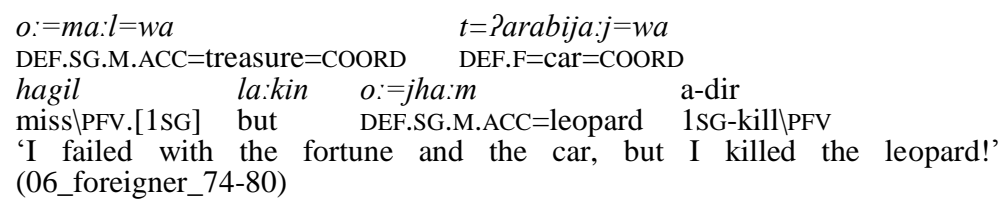

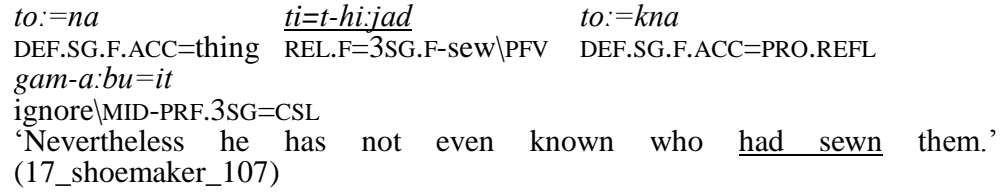

9 'The Perfective has a terminative value'.

10 'The function of the perfective paradigm is to mark a bounded, delimited process or state. It expresses "a predicative relation as occurred and constituting an event" (Cohen 1989: 67), independently of a temporal reference point. Consequently, this paradigm is neutral from a temporal viewpoint and is found in past, present, and future contexts, even though the latter is rarer.' 
(8)
dann? $i=e$ :
to: $=n a$
manni-im-an
dolIPFV. [2SG]=REL DEF.SG.F.ACC=thing wish-MID-PFV.1SG

'I wish (PFV) that you do it' (02_farmer_275)

(9)
Panbi:k=e:k
$s a f=w a$
haraw $=w a$
anu
takelIPFV.[2SG.M]=if dowry=COORD engament_dowry=COORD without $\underline{a-d ? i r}=h o: k$
1SG-marry $\backslash \mathrm{PFV}=\mathrm{OBJ} .2 \mathrm{SG}$
'If you take it, I'll marry you without a dowry and an engagement dowry.'
(36_hunchback_165)

\section{"Aorist"}

As mentioned in Section 3.1, "The in-form", the label "aorist" was introduced by Munzinger (1864) for the in-form but was not taken up in later descriptions for this finite form. Instead the Austrian linguist Friedrich Müller reused it in his 1865 comparative sketch of Beja for the $i$-form, and it was reintroduced much later by comparatists, first by Voigt (1988), seemingly on the basis of a comparison with Akkadian (Semitic) and Berber languages for the $i$-form, then by Appleyard (2007) for the $i$--form. The latter's brief functional justification for his "aorist" label runs as follows:

The aorist tense Reinisch calls "pluquamperfect," Roper "conditional," and Hudson "past" (what he calls "preterite" I have here called past). Hudson's glosses indicate a tense referring variously to a remote or anterior past event, a continuous or on-going past event or a doubtful event, while in Roper the same form seems to be used mainly in the apodosis of unreal conditions. Almkvist's informants were apparently unfamiliar with such a tense, though Almkvist notes that Munzinger had recorded a "plusquamperfekt"11 (Almkvist 1881: 136, §182). (Appleyard 2007: 468)

We are reminded here again of the influence of the Classical Greek grammatical tradition.

I later reused this label for the same form as Appleyard. My decision had nothing to do with the Greek and Indo-European traditions, but rather with three other factors. The first one was my own analysis of the meanings and functions of the $i$ :-form in spontaneous speech; the second was the necessity to find a label that was neither temporally connected with past tense, perfective or imperfective aspect, nor connected to a modal stance. The third factor was not fully conscious, and had to do with my academic training in Afroasiatic linguistics, in particular Semitic, where the term is traditionally used for Akkadian, and Berber. For instance Galand characterizes the Berber "aorist" as follows:

Forme non marquée, l'aoriste employé sans particule se prête à l'expression de n'importe quel aspect et ne tient sa valeur que du contexte. Si l'on excepte quelques constructions particulières, cela implique que l'aoriste n'est pas le premier verbe de l'énoncé. Par conséquent, sa présence suffit à lier en quelque façon la proposition

${ }^{11}$ Reinisch seems to have also taken up the label from Munzinger. 
dans laquelle il se trouve à celle qui précède. Il entre indifféremment dans une description de portée générale, dans un récit historique, dans un conte, etc. Galand (1977: 298-299) $)^{12}$

This characterization of the Berber "aorist" fits quite well in both meaning and function with the $i$-form of Beja. The vast majority (75\%) of uses of this form in my data occur in subordinate clauses, and the verb form of the main clause which they are dependent on can be that of any finite verb paradigm, meaning that the $i$-form is not connected to any particular temporal or situational reference point. This is also the case in its less frequent usages in main or independent clauses, where it is used for habitual (10) (usually towards the beginning of tales, and in procedural texts), and repetitive actions (11), general truth (11), and reportive meaning (12), in back-grounded contexts, typically in tail-head linkage constructions (13), to mark the anteriority of a process as compared to another (14) (hence, perhaps, the label of pluperfect used by Munzinger, Reinisch, and Wedekind), and at the end of a clause chain (15). Such restrictions on the use of a verb paradigm are typical of situations where an old form is marginalized to backgrounded contexts under the pressure from a new form (see e.g. Cohen 1984; Bybee et al. 1994).

(10)

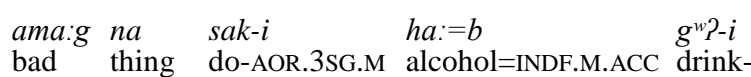

'[A man was living in a country,] he was doing bad things, he was drinking alcohol.' (08_drunkard_005)

$$
\begin{array}{llll}
\text { khara:j } & a k-e: t i: t=k a & e: n & i=k a r a j=e: b \\
\text { hyena } & \text { become-CVB.SEQ=DISTR } & \text { PROX.PL.M.ACC } & \text { DEF.M=hyenalPL=LOC.PL }
\end{array}
$$
$t i=$ msu: sana $j=t=0$ : $\quad$ tam- $t i$

DEF.F=carrion=INDF.F=POSS.3SG.ACC eat-AOR.3sG.F

'Each time she was becoming a hyena, she was eating her carrion among the hyenas.' (35_hyena-djinns_14-17)

$$
\text { adgir- } a=b \quad \text { aka-je: alla:ji- } i=\text { dha } \quad i:-3 i f
$$

can-CVB.MNR=INDF.M.ACC become-CVB.SMLT God-GEN=DIR 1sG-letlAOR

'Even if I can face it, I leave it to God.' (01_rich_SP2_254)

$$
\begin{array}{llll}
i f-t i & \text { gi:g-i:ni } & i f-t i & g i \cdot g-i=h o: b \\
\text { let-CVB.GNRL } & \text { leave-INAC.3sG.M } & \text { let-CVB.GNRL } & \text { leave-AOR.3SG.M=when }
\end{array}
$$

'He left without them. When he left without them...' (18_Adam_devil_288290)

12 'An unmarked form, the aorist used without a particle lends itself to the expression of any aspect and takes its value from the context. With the exception of a few particular expressions, this implies that the aorist is not the first verb of an utterance. Consequently, its presence is enough to link, in whatever way, the clause in which it occurs to the preceding one. It equally occurs in a description of a general scope, in a historical account, in a tale, etc.' 
(14)

$\begin{array}{lll}i=\text { gabal } & i=t=h a d ? a: n i & t i:-d=e:-n=a: j\end{array}$

DEF.M=direction REL.M=DEF.F=old_person 3SG.F-say\AOR=REL-EP=ABL

i-ndi:f

3sG.M-leavelIPFV

'He leaves in the direction the old woman had said.' (25_orphan_068-071)

(15) dha:j $j$ ? $-i=t$

DIR venir-AOR.3SG.M=COORD

['After his arrival at Adam's, when he makes leaves rustle (IPFV) next to him, after Adam has observed (CVB.SEQ) like that, with his hands put on his forhead, he watches (INAC). When Hedgehog looks (IPFV), he understands (IPFV) that Adam does not see him (OPT).'13] 'He comes towards them and...' (18_Adam_devil_059)

\section{"Conditional"}

The label "conditional" only concerns the $i$-form. It was introduced by Roper (1928: 48), obviously on the basis of its usage in both the protasis and apodosis of conditional clauses, even though he was aware of other uses of this finite form: "The conditional often serves as an imperfect or continuous past tense" (Roper 1928: 51). The label was reused by Morin (1995: 52) who only mentions its usage in the protasis of conditional clauses: "On appelle conditionnel un thème subordonné à désinence /i/ qui, selon les contextes, présente une éventualité passé, présente ou à venir". ${ }^{14}$ As shown in the discussion of the label "aorist" (Section 3.2.5, "Aorist"), the use of this finite form goes far beyond a conditional mood.

\section{COMPARATIVE APPROACHES}

Cohen, Zaborski, Voigt and Appleyard (2004), who all worked with second-hand data and descriptions, were concerned with the morphosyntactic evolution of the Beja system as compared with those of Cushitic and Afroasiatic (mainly its Semitic branch). Building on a hypothesis proposed by Reinisch (1894: 177) for Zaborski (1975) and Appleyard (2004), apparently independently of Cohen $(1972,1973)$ who refined Reinisch's hypothesis - they all ${ }^{15}$ agree that the inform (their "imperfective" or "present") was renewed (at least partially) by the grammaticalization of a new "imperfective" ("present" or "progressive") form with an auxiliary meaning 'be; say' in the perfective/past form. The introduction of this new paradigm supposedly restricted the $i$-form (the "old present" of Zaborski, the "perfective" or "past" of most of the others) to past

13 The optative is obligatory in negative completive clauses (Vanhove 2017a: 137).

14 'A subordinated stem with a flexional ending /i/, which, depending on the context, displays an eventuality as past, present, or future').'

15 Two exceptions, which do not need to be discussed for the purposes of this paper, are Banti (2004), who hypothesizes a debatable evolution based on phonological and analogical processes of inherited cognates of the Afroasiatic stative conjugation, and Voigt (1988). 
contexts, where it eventually became a "perfective" (or "past"), while the $i$ :form, the former "perfective" / "past" (with the same back vowel $a$ as the perfective aspect of other Cushitic languages) became what Cohen (1973: 60) described as "une sorte de passé modal" ['a kind of modal past']. The limitations of the use of the $i$-form over the course of the evolution of the Beja language gave rise to a wealth of labels: "plusquamperfect", "conditional", "past", "old past", "perfect", "aorist", some obviously borrowed from former descriptions or recycled from Western or Indo-Europeanist traditions, others ("old present" and "old past") created for the purpose of comparison. For these authors, labels seem to have acted as convenient tools for naming forms and paradigms and finding their way (and showing readers the way) around the literature about Beja or comparison with Cushitic, rather than as functional and semantic labels. None of them provided an explanation for their labels.

\section{CONCLUSION}

This historical overview of the indicative finite verb forms has shown that several reasons may have induced the choice of labels by linguists who have worked on Beja since the second half of the $19^{\text {th }}$ century. These scholars can be divided into two groups: descriptivists and comparatists. The former mostly adapted existing terminology from various linguistic traditions, rarely explicitly, while the latter mostly recycled it. Apart from this division, several factors behind the choice of a label can be inferred, or are sometimes given by the authors, beyond the almost universal lack of in-depth functional and semantic analysis of the verb forms which led to competing and confusing terminology sets. There is a clear-cut distinction between temporal and aspectual labels which correlates with the historical development of aspectual theories, and also with the linguistic traditions for Greek, Indo-European and Afroasiatic (in particular Semitic and Berber). But labels are also linked to "national" grammatical traditions, corresponding either to the native language of the authors or to the language in which the grammars were written, namely German, English and French. Grammars written in German are the oldest, and their labels conform to the classical philological tradition of their time, even if at times it is contradictory. In the most recent publication by German-speaking linguists (Wedekind \& Wedekind 2007), an aspectual stance is adopted by the authors, but they hesitate between temporal and aspectual labels, a mixture which is also found, to various extents, in works by French (Morin) and Swedish (Dahl) linguists. Descriptions of the three finite verb forms by British scholars and the Swedish typologist Östen Dahl show competing influences: British terminology, the philological tradition, but also the first steps towards a more detailed analysis of the functions of the paradigms based on a theory of aspect and a questionnaire (Dahl). The French linguists on the other hand belong to the most recent layer of specialists of Beja and were both trained in Semitic and Afroasiatic linguistics (for which aspectual analyses predominate since Marcel Cohen's thesis published in 1924) and in aspectual theories. Nevertheless both of them took up existing labels for the $i$--form from British linguists, from Roper for Morin (the 
modal "conditional"), and from Appleyard for Vanhove (2017) (the aspectual "aorist"). In any case, what is constant among all the authors is the manifold influences and the impact of traditional labels, whatever their origin.

The above overview of the history of verb paradigm labels in Beja does not claim to be a contribution to the history of aspect, or more broadly of TAM-s, but provides an illustration of how and why labels are manipulated, more often unconsciously than consciously, by linguists. ${ }^{16}$

\section{REFERENCES}

Almkvist H., 1881-1885, Die Bischari-Sprache Tū-Beḍ̄wie in Nordost-Afrika, Upsala: Kaiserliche Akademie der Wissenschaften.

Appleyard D., 2004, Beja as a Cushitic language, in Gabor Takács (ed.), Egyptian and Semito-Hamitic (Afro-Asiatic) Studies in Memoriam Werner Vycichl, Leiden, Boston, Brill, p. 173-194.

Appleyard, David. 2007. Beja morphology. In A.S. Kaye (éd.), Morphologies of Asia and Africa, 447-480. Winona Lake (Indiana): Eisenbrauns.

Banti, Giorgio. 2004. New Perspectives on the Cushitic Verbal System. In Andrew Simpson (ed.), Proceedings of the Twenty-Seventh Annual Meeting of the Berkeley Linguistics Society (March 22-25, 2001) - Special Session on Afroasiatic Languages, 1-48. Berkeley: Berkeley Linguistics Society.

Bybee, Joan L. and Perkins, Revere and Pagliuca, William. 1994. The evolution of grammar: Tense, aspect and modality in the languages of the world. Chicago: The University of Chicago Press.

Cohen, David. 1972. La mutation aspectivo-temporelle dans quelques langues couchitiques et le système verbal chamito-sémitique. In Jacqueline Thomas \& Lucien Bernot (eds.), Langues et Techniques, Nature et Société, 57-63. Paris: Klincksieck.

Cohen, David. 1973. Le renouvellement de l'inaccompli en bédawiye. Comptes Rendus du GLECS 1969-1970: 14. 69-78.

Cohen, David. 1984. La phrase nominale et l'évolution du système verbal en sémitique. Etude de syntaxe historique. Leuven, Paris: Peeters.

Cohen, David. 1988. Bédja. In David Cohen (ed.), Les langues dans le monde ancien et moderne. Langues chamito-sémitique, 270-277. Paris: Editions du CNRS.

Cohen, David. 1989. L'Aspect. Paris: Presses Universitaires de France.

Cohen, Marcel. 1924. Le sémitique et l'expression du temps. Paris: Imprimerie Nationale.

Comrie. Bernard. 1976. Aspect. An Introduction to the Study of Verbal Aspect and Related Problems. Cambridge: Cambridge University Press.

Dahl, Östen. 1984. Sketch of the TMA system of Beja. In Östen Dahl and D. Kós-Dienes (eds.), Selected working papers from the tense-mood-aspect project, 92-99. Stockholm: Institute of Linguistics, University of Stockholm.

Hudson, Richard A. 1964. A Grammatical Study of Beja. London: University of London. (PhD dissertation.)

Hudson, Richard A. 1974. A Structural Sketch of Beja. African Languages Studies 15: 111-142.

16 For a very interresting overview of the question, see Samain (1996: VII-LIII). 
Hudson, Richard A. 1976. Beja. In Lionel M. Bender (ed.), The Non-Semitic Languages of Ethiopia, 97-132. East Lansing, Michigan: African Studies Center, Southern Illinois University.

Morin, Didier. 1995. "Des paroles douces comme la soie". Introduction aux contes dans l'aire couchitique (bedja, afar, saho, somali). Paris: Peeters

Müller, Friedrich. 1865. Über die Sprache der Beğa im nordöstlichen Afrika. Orient und Occident 3:1-3 (1864-1866): 336-347.

Munzinger, Werner. 1864. Ostafrikanische Studien. Schaffhausen: Fr. Hurtersche Buchhandlung.

Reinisch. Leo. 1893-1894. Die Bedauye-Sprache in Nordost-Afrika, 3 vol. Wien: Tempsky (Akademie der Wissenschaften in Wien, Philosophisch-Historische Klasse, 130,7)

Roper, E. M. 1928. Tu Bedawic. An Elementary Handbook for the Use of Sudan Government Officials. Hertford: Stephen Austin.

Samain, Didier. 1996. Préface. In Erwin Koschmieder, Les rapports temporels fondamentaux et leur expression linguistique. Contribution à la question de l'aspect et du temps. Traduction et commentaire par Didier Samain, pp. VIILIII. Villeneuve d'Ascq: Presses Universitaires du Septentrion.

Vanhove, Martine. 2014a. Beja Grammatical Sketch. In Amina Mettouchi \& Christian Chanard (eds), The CorpAfroAs Corpus of Spoken AfroAsiatic Languages. (http://dx.doi.org/10.1075/scl.68.website) (Accessed 12 June 2017).

Vanhove, Martine. 2014b. The Beja Corpus. In Mettouchi, Amina \& Chanard, Christian (eds), The CorpAfroAs Corpus of Spoken AfroAsiatic Languages. (http://dx.doi.org/10.1075/scl.68.website) (Accessed 12 June 2017).

Vanhove, Martine (avec la collaboration de Mohamed-Tahir Hamid Ahmed \& Ahmed Abdallah Mohamed-Tahir). 2017a. Le bedja. Leuven, Paris: Peeters.

Vanhove Martine. 2017b. The Beja Corpus. In Mettouchi, Amina \& Chanard, Christian (eds), The CorTypo Corpus of Spoken AfroAsiatic Languages. http://cortypo.huma-num.fr/Archives/cortypo. Php. (Accessed 12 June 2017).

Voigt, Rainer. 1988. Zur Bildung des Präsens im Bedauye. In Mariane Bechhaus-Gerst and Fritz Serzisko (eds.), Cushitic-Omotic, International Symposium on Cushitic and Omotic Languages, Cologne, January 6-9 1986, 379-407. Hamburg: Helmut Buske.

Wedekind, Klans \& Charlotte. 2007. A Learner's Grammar of Beja (East Sudan). Köln: Rüdiger Köppe.

Zaborski, Andrzej. 1975. The Verb in Cushitic. Krakow: Nakladem Uniwersytetu Jagiellonskiego. 